\title{
Phet Simulation as Means to Trigger the Creative Thinking Skills of Physics Concepts
}

\author{
https://doi.org/10.3991/ijet.v15i06.11319 \\ Habibi Habibi $\left({ }^{\bowtie}\right)$, Jumadi Jumadi, Mundilarto Mundilarto \\ Yogyakarta State University, Yogyakarta, Indonesia \\ habibi.2016estudent.uny.ac.id
}

\begin{abstract}
Creative thinking skills are very important in solving difficult physics concepts, therefore the right strategies are needed as a trigger. This study has analyzed the implications of learning technology assisted by Physics educational technology (Phet) on creative thinking skills. The type of research is pre-experiment with one group pretest-posttest design. The sample involved 32 early semester students from one private university, west Nusa Tenggara, Indonesia. Data has been collected using creative thinking essay tests that are adjusted to creative thinking skills-Kim indicators. Descriptive-parametric statistics are used to analyze research data. The results have shown that there are differences in the improvement scores at each indicator of fluency, flexibility, originality, and elaboration. The findings mean that Phet has positive implications for CrTS. In detail, it was presented in the discussion.
\end{abstract}

Keywords-Phet simulation, creative thinking skills, physics concepts

\section{Introduction}

Physics concepts are very complicated, therefore requiring high-level thinking skills such as creative thinking to solve problems [1,2]. Creative thinking is related to the complexity of intellectual thinking. In the learning process, creative thinking is a number of knowledge conflicts to find different solutions for the same problem, therefore it is highly recommended to solve open and complicated problems [3]. Ineffective learning strategies can lead to less developed creative thinking. The psychological impact is that students become dependent, unconfident, and pessimistic to present their findings [4].

Creative thinking is one of the basic skills in the curriculum of developed countries and is not easily taught in conventional classrooms, some of which have succeeded in becoming the best educated country in the world [3]. In 2018, WEFFI released that Finland, Switzerland and New Zealand were the best education providers who were very concerned about creative skills for the future. This means that creative thinking is an important skill to survive in the present and future [5]. This skills help to generate new methods and concepts [6], enrich ideas that are interconnected, and solve problems circularly [7], even able to reduce anxiety and increase positive emotions 
[8]. Treffinger [9] emphasizes that everyone has the potential to think creatively. However, the ability to choose the right strategy is needed as a trigger [10].

The use of interactive media from Physics education technology is an alternative learning strategy. The features provided help students analogize abstract physics concepts and require mathematical logic [11]. Students can explore their creative abilities to find new alternatives such as proposing various ideas (fluency), various solution approaches (flexibility), offering new alternatives (originality), and being able to explain easily (elaboration) [12].

Previous research has not been widely used to explore students' creative thinking skills in higher education. Some other implications are focused on understanding physics concepts [13-16], maximizing involvement in learning [17], effectiveness in learning physics [18], stimulating class discussions [19, 20], improving learning processes and outcomes [21], motivation and conceptual understanding [22], scientific inquiry [23], and problem solving [24, 25].

Presently, creative thinking in the era of technology is one indicator of the quality of education in a country, even an important ability for the future [26]. The use of technology is one of the efforts to increase it through the information technology approach. This study discusses the implications for students' creative thinking skills in higher education.

\section{Methodology}

This research is a pre-experiment with one group pretest-posttest design. A sample of 32 people was the first semester students in basic physics lectures at one of the private universities in west Nusa Tenggara. Creative thinking skills are triggered by interactive simulations and are freely accessed via https://phet.colorado.edu/. Data collection is done by essay tests that refer to the four CrTS-Kim indicators (fluency, flexibility, originality, and elaboration). Inferential analysis is involved as a prerequisite test in determining the contribution of Phet simulations to each CrTS indicator. Improvements in implications are obtained from the $\mathrm{N}$-gain test. The categorization of $\mathrm{N}$-gain scores refers to the Hake categories [27] as follows:

$$
\mathrm{N}-\text { gain }(\mathrm{g})=\frac{\text { Postets }- \text { Pretest }}{\text { Maks. score }- \text { Pretest }}
$$

Table 1. Categorizing creative thinking skills

\begin{tabular}{|c|l|}
\hline N-gain $(\mathrm{g})$ scores & \multicolumn{1}{c|}{ Categories } \\
\hline $\mathrm{g}>0.7$ & High \\
\hline $0.3 \leq \mathrm{g} \leq .7$ & Medium \\
\hline $\mathrm{g}<0.3$ & Low \\
\hline
\end{tabular}


Based on Table 1, each CrTS indicator score refers to three $\mathrm{N}$-gain categories, namely high, medium, and low. The analysis of prerequisite tests (normality and homogeneity) using SPSS 18.0 software.

\section{$3 \quad$ Results and Discussion}

Preliminary data analysis was conducted to determine the prerequisite test for normality and homogeneity. The normality test of data based on the number of samples is the Shapiro-Wilk method. According to Razali and Wah [28] Shapiro-Wilk is recommended for small samples or less than 50 and sig. $>0.05$. The test results show that the distribution of data on each CrTS indicator (variant) has been normally distributed (Table 2). Furthermore, Levene's test (homogeneity) was conducted to find out the similarity of variants from the pretest-posttest data. Levene's test is needed as an additional prerequisite, although not all parametric tests involve it. Data is considered homogeneous if sig. $>0.05$. The analysis results show that each CrTS indicator has sig. > 0.05, therefore it meets the homogeneous criteria (Table 3).

Table 2. Result of test normality

\begin{tabular}{|l|c|c|c|c|c|}
\hline \multirow{2}{*}{\multicolumn{1}{c|}{$\begin{array}{c}\text { Indicators } \\
\text { (Variant) }\end{array}$}} & Pretest score & Sig. & Posttest score & Sig. & \multirow{2}{*}{ N } \\
\cline { 2 - 5 } & 0.947 & 0.12 & 0.941 & 0.78 & \\
\hline Fluency & 0.937 & 0.06 & 0.948 & 0.13 & \multirow{2}{*}{32} \\
\hline Flexibility & 0.939 & 0.07 & 0.951 & 0.15 & \\
\hline Originality & 0.943 & 0.09 & 0.957 & 0.22 & \\
\hline Elaboration & & &
\end{tabular}

Table 3. The homogeneity test results for each indicator (Levene's test)

\begin{tabular}{|l|c|c|c|}
\hline \multicolumn{1}{|c|}{ Indicators (Variant) } & Levene's test & Sig. & N \\
\hline Fluency & 1.234 & 0.296 & \\
\hline Flexibility & 1.537 & 0.220 & \multirow{2}{*}{32} \\
\hline Originality & 2.815 & 0.065 & \\
\hline Elaboration & 1.467 & 0.236 & \\
\hline
\end{tabular}

$\mathrm{N}$-gain analysis is carried out after meeting the requirements for normality and homogeneity. The increase in each CrTS indicator in basic physics learning can be demonstrated by this analysis. The category of N-gain scores is strongly influenced by the increase in student pretest-posttest scores. Analysis results (Table 4) represent Phet's contribution in each CrTS indicator. The number of students categorized as 'High' on the fluency indicator is $41 \%$, while 'Medium' and 'Low' categories are $34 \%$ and $25 \%$. This means that most students have high creativity on fluency indicators. The increase in flexibility and originality indicators is dominated by the 'Medium' category, which is $72 \%$ and $53 \%$, others categorized as 'Low'. This means that the score difference between student pretest-posttest is not much different; therefore it is not 'high' category. The last category is elaboration, mostly categorized as 'Medium' (50\%), others 'High' (28\%) and 'Low' (22\%). 
Table 4. Profile of CrTS indicators in each category

\begin{tabular}{|l|c|c|c|c|}
\hline \multirow{2}{*}{ N-gain Categories } & \multicolumn{4}{|c|}{ CrTS Indicators } \\
\cline { 2 - 5 } & Fluency & Flexibility & Originality & Elaboration \\
\hline High & 0.41 & 0.0 & 0.0 & 0.28 \\
\hline Medium & 0.34 & 0.72 & 0.53 & 0.50 \\
\hline Low & 0.25 & 0.28 & 0.47 & 0.22 \\
\hline
\end{tabular}

Typical contributions based on the average $\mathrm{N}$-gain score on each indicator are categorized as 'Medium' (Graph 1). This means that the effect of applying Phet in physics learning has a considerable contribution in increasing CrTS.

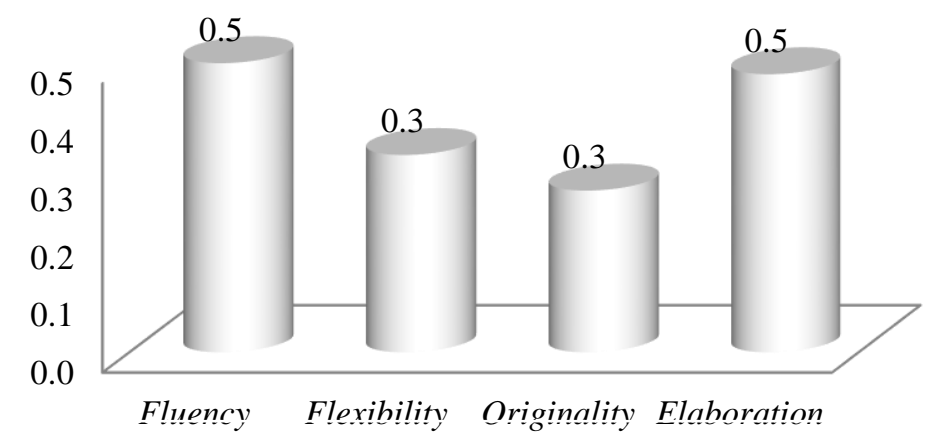

Fig. 1. Graph 1 Profile of the average N-gain score for each indicator

The fluency category has reciprocity in the categories of flexibility, originality, and elaboration. This means that success in the next creative process is determined by fluency ability [29]. In addition, learning that is oriented towards learning objectives can maximize student fluency abilities [30].

Various factors can cause different levels of student creative thinking. Every student has intellectual differences in thinking to understand physics concepts. Completion of cases with the same ways and conditions can cause student creativity not to develop. According to Oslon [31] that habitual and pessimism (fear of failure, limited completion time, worry in criticism) are inhibiting factors of creative thinking. This means that an open minded attitude must be accustomed, confident, and optimism is required [32]. However, for the level of higher education students are required to be adept at solving various cases of physics with creative solutions, therefore educators must be selective in choosing the right learning strategy and using open problems for triggering CrTS. 


\section{Conclusion}

These results have shown that Phet simulations have positive implications for increasing CrTS in physics concepts. This profile has been presented by an increase in CrTS indicator scores.

\section{Acknowledgement}

This research is supported by the Ministry of Finance and Research and Technology (LPDP \& DIKTI) through BUDI DN scholarship program.

\section{References}

[1] Peters, P. C. (1982). Even honors students have conceptual difficulties with physics. American journal of physics, 50(6), 501-508. https://aapt.scitation.org/doi/abs/10.111 9/1.12797 https://doi.org/10.1119/1.12797

[2] Kim, E., \& Pak, S. J. (2002). Students do not overcome conceptual difficulties after solving 1000 traditional problems. American Journal of Physics, 70(7), 759-765. https://aapt. scitation.org/doi/abs/10.1119/1.1484151 https://doi.org/10.1119/1.1484151

[3] Mumford, M. D., Medeiros, K. E., \& Partlow, P. J. (2012). Creative thinking: Processes, strategies, and knowledge. The Journal of Creative Behavior,46(1), 30-47. https://onlinelibrary.wiley.com/doi/abs/10.1002/jocb.003 https://doi.org/10.1002/jocb.003

[4] Zhou, J., \& Oldham, G. R. (2001). Enhancing creative performance: Effects of expected developmental assessment strategies and creative personality. The Journal of Creative Behavior, 35(3), 151-167. https://onlinelibrary.wiley.com/doi/abs/10.1002/j.2162-6057.2001. tb01044.x https://doi.org/10.1002/j.2162-6057.2001.tb01044.x

[5] Songkram, N. (2017). Online Course Design for Creativity and Innovative Skills in Virtual Cultural ASEAN Community. International Journal of Emerging Technologies in Learning, 12(1). https://doi.org/10.3991/ijet.v12i01.6032

[6] Gilhooly, K. J., Fioratou, E., Anthony, S. H., \& Wynn, V. (2007). Divergent thinking: Strategies and executive involvement in generating novel uses for familiar objects. British Journal of Psychology, 98(4), 611-625. https://doi.org/10.1111/j.2044-8295.2007.tb00467 $\underline{\mathrm{X}}$

[7] Michalko, M. (2010). Thinkertoys: A handbook of creative-thinking techniques. Ten Speed Press.

[8] Stuckey, H. L., \& Nobel, J. (2010). The connection between art, healing, and public health: A review of current literature. American journal of public health, 100(2), 254-263. https://ajph.aphapublications.org/doi/abs/10.2105/AJPH.2008.156497 https://doi.org/10.21 05/ajph.2008.156497

[9] Treffinger, D. J., Isaksen, S. G., \& Stead-Dorval, K. B. (2005). Creative problem solving: An introduction. Prufrock Press Inc.

[10] Tofade, T., Elsner, J., \& Haines, S. T. (2013). Best practice strategies for effective use of questions as a teaching tool. American journal of pharmaceutical education, 77(7), 155. https://doi.org/10.5688/ajpe777155 https://doi.org/10.5688/ajpe777155 
[11] Finkelstein, N., Adams, W., Keller, C., Perkins, K., \& Wieman, C. (2006). Hightech tools for teaching physics: The physics education technology project. Journal of Online Learning and Teaching, 2(3), 110-121.

[12] Kim, K. H. (2011). The creativity crisis: The decrease in creative thinking scores on the Torrance Tests of Creative Thinking. Creativity Research Journal, 23(4), 285-295. https:// doi.org/10.1080/10400419.2011.627805

[13] Perkins, K., Adams, W., Dubson, M., Finkelstein, N., Reid, S., Wieman, C., \& LeMaster, R. (2006). PhET: Interactive simulations for teaching and learning physics. The physics teacher, 44(1), 18-23. https://doi.org/10.1119/1.2150754

[14] Wieman, C. E., Adams, W. K., \& Perkins, K. K. (2008). PhET: Simulations that enhance learning. Science, 322(5902), 682-683. https://doi.org/10.1126/science.1161948

[15] Faour, M. A., \& Ayoubi, Z. (2018). The effect of using virtual laboratory on grade 10 students' conceptual understanding and their attitudes towards physics. Journal Of Education In Science Environment And Health, 4(1), 54-68. https://doi.org/10.21891/jeseh.387482

[16] Abdurrahman, A., Saregar, A., \& Umam, R. (2018). The effect of feedback as soft scaffolding on ongoing assessment toward the quantum physics concept mastery of the prospective physics teachers. Jurnal Pendidikan IPA Indonesia, 7(1), 41-47. https://doi.org/ 10.15294/jpii.v6i2.7239

[17] Adams, W. K., Reid, S., LeMaster, R., McKagan, S. B., Perkins, K. K., Dubson, M., \& Wieman, C. E. (2008). A study of educational simulations part I-Engagement and learning. Journal of Interactive Learning Research, 19(3), 397-419. https://doi.org/10.1142/97 89812813787_0097.

[18] Wieman, C. E., Perkins, K. K., \& Adams, W. K. (2008). Oersted Medal Lecture 2007: Interactive simulations for teaching physics: What works, what doesn't, and why. https://doi. org/10.1119/1.2815365

[19] McKagan, S. B., Perkins, K. K., Dubson, M., Malley, C., Reid, S., LeMaster, R., \& Wieman, C. E. (2008). Developing and researching PhET simulations for teaching quantum mechanics. American Journal of Physics, 76(4), 406-417. https://doi.org/10.1119/1.28851 $\underline{99}$

[20] Urban-Woldron, H. (2009). Interactive simulations for the effective learning of physics. Journal of Computers in Mathematics and Science Teaching, 28(2), 163-176. https:// www.learntechlib.org/primary/p/30299/.

[21] Rutten, N., Van Joolingen, W. R., \& Van der Veen, J. T. (2012). The learning effects of computer simulations in science education. Computers \& Education, 58(1), 136-153. https ://doi.org/10.1016/i.compedu.2011.07.017

[22] Prima, E. C., Putri, A. R., \& Rustaman, N. (2018). Learning Solar System Using PhET Simulation to Improve Students' Understanding and Motivation. Journal of Science Learning, 1(2), 60-70. https://doi.org/10.17509/jsl.v1i2.10239

[23] Chen, S. (2010). The view of scientific inquiry conveyed by simulation-based virtual laboratories. Computers \& education, 55(3), 1123-1130. https://doi.org/10.1016/j.compedu. 2010.05.009

[24] Ceberio, M., Almudí, J. M., \& Franco, Á. (2016). Design and application of interactive simulations in problem-solving in university-level physics education. Journal of Science Education and Technology, 25(4), 590-609. https://doi.org/10.1007/s10956-016-9615-7

[25] Wartono, W., Suyudi, A., \& Batlolona, J. R. (2018). Students' Problem Solving Skills of Physics on the Gas Kinetic Theory Material. Journal of Education and Learning, 12(2), 319-324. https://doi.org/10.11591/edulearn.v12i2.8424 
[26] Shubina, I., \& Kulakli, A. (2019). Pervasive Learning and Technology Usage for Creativity Development in Education. International Journal of Emerging Technologies in Learning, 14(1). https://doi.org/10.3991/ijet.v14i01.9067

[27] Hake, R. R. (1998). Interactive-Engagement versus traditional methods: A six-thousandstudent survey of mechanics test data for introductory physics courses. American Journal of Physics, 66 (1), 64-74. https://doi.org/10.1119/1.18809

[28] Razali, N. M., \& Wah, Y. B. (2011). Power comparisons of shapiro-wilk, kolmogorovsmirnov, lilliefors and anderson-darling tests. Journal of statistical modeling and analytics, 2(1), 21-33.

[29] Clark, P. M., \& Mirels, H. L. (1970). Fluency as A Pervasive Element in The Measurement Of Creativity. Journal of Educational Measurement, 7(2), 83-86. https://doi.org/10. $\underline{1111 / j .1745-3984.1970 . t b 00699 . x}$

[30] Hill, M., Sharma, M. D., \& Johnston, H. (2015). How online learning modules can improve the representational fluency and conceptual understanding of university physics students. European Journal of Physics, 36(4), 045019. https://doi.org/10.1088/0143-0807/36 /4/045019/meta https://doi.org/10.1088/0143-0807/36/4/045019

[31] Olson, R. W. (1980). The art of creative thinking (Vol. 508). Barnes \& Noble.

[32] Nonthamand, N., \& Nasss-Songkhla, J. (2018). The Correlation of Open Learning, Collaboration, Learning Tools, and Creative Problem Solving by Graduate Students in Thailand. International Journal of Emerging Technologies in Learning (iJET), 13(09), 280289. https://doi.org/10.3991/ijet.v13i09.7835

\section{Authors}

Habibi Habibi is Doctor Candidates at Yogyakarta State University, Indonesia. He is a lecturer in the Department of Physics Education, IKIP Mataram, and has experience in physics education research, development of learning models, and computer technology.

Mundilarto and Jumadi are lecturers of undergraduate and postgraduate program of Yogyakarta State University. Their researches related to science and technology are widely indexed both in the National and International journals.

Article submitted 2019-07-17. Resubmitted 2019-09-02. Final acceptance 2019-09-21. Final version published as submitted by the authors. 